\title{
Uwarunkowania prawne wdrożenia mechanizmów wsparcia dla funkcjonowania terminalu LNG w Świnoujściu
}

\begin{abstract}
Mimo rozbudowy interkonektorów gazowych na zachodniej i południowej granicy Polska nadal jest nadmiernie uzależniona od dostaw gazu ze Wschodu i narażona na ryzyko zakłóceń tych dostaw w związku z sytuacją geopolityczną. W tym kontekście terminal LNG w Świnoujściu ma kluczowe znaczenie dla bezpieczeństwa energetycznego Polski, jako nowy punkt wejścia do krajowego systemu przesyłowego (KSP), zapewniający dostęp do światowego rynku LNG i umożliwiający dywersyfikację źródeł dostaw gazu. Jednocześnie, uwzględniając obecne realia rynkowe, za prawdopodobny należy uznać scenariusz, w którym koszty dostaw realizowanych za pośrednictwem terminalu LNG w Świnoujściu mogą okazać się wyższe w porównaniu z kosztami dostaw realizowanych przez inne punkty wejścia do KSP, co skutkować może relatywnie niewielkim popytem na usługi terminalu. W artykule zostały przedstawione ramy prawne potencjalnego wdrożenia mechanizmów zwiększających konkurencyjność i dostępność terminalu LNG dla uczestników rynku.
\end{abstract}

Słowa kluczowe: terminal LNG w Świnoujściu, bezpieczeństwo energetyczne, dywersyfikacja dostaw gazu, mechanizm wsparcia, usługi świadczone w ogólnym interesie gospodarczym.

\section{Legal aspects of the implementation of support mechanisms for the operation of the Swinoujscie LNG terminal}

\begin{abstract}
Despite the expansion of gas interconnectors on its western and southern borders, Poland is still excessively dependent on gas supply from the east and exposed to the risk of a disruption of supply due to the geopolitical situation. In this context, the LNG terminal in Swinoujscie will be of crucial importance for the energy security of Poland as a new entry point to the National Transmission System (NTS), providing access to the global LNG market and opportunities for the diversification of gas supply sources. At the same time, taking into account current market realities, a possible scenario should be considered in which, the cost of deliveries through the terminal will be significantly higher than the cost of deliveries through other entry points to the NTS, which may result in relatively low demand for the services of the terminal. The article presents the legal framework of the potential implementation of mechanisms to increase the competitiveness and availability of LNG to market participants.
\end{abstract}

Key words: the Swinoujscie LNG terminal, energy security of Poland, diversification of gas supply, support mechanism, services of general economic interest.

\section{Aktualny stan zdywersyfikowania dostaw gazu na terytorium Polski}

W ostatnich latach obserwujemy wzrost udziału przywozu gazu z kierunków innych niż wschodni w całkowitym bilansie dostaw realizowanych na terytorium Polski [przywóz gazu oznacza sprowadzenie na terytorium Rzeczypospolitej Polskiej gazu ziemnego w ramach nabycia wewnątrzwspólnotowego lub importu, zgodnie z art. 2 pkt 14 ustawy o za- pasach ropy naftowej, produktów naftowych i gazu ziemnego oraz zasadach postępowania w sytuacjach zagrożenia bezpieczeństwa paliwowego państwa i zakłóceń na rynku naftowym z dnia 16 lutego 2007 r. (Dz. U. z 2014 r. poz. 1695 z późn. zm.)]. W 2011 r. udział importu gazu ze Wschodu w całkowitym bilansie dostaw (przywóz, tj. import i nabycie 
wewnątrzwspólnotowe, i wydobycie krajowe) wynosił 60,77\% (a udział w całkowitym przywozie - 85,53\%), natomiast w 2014 r. udział ten był równy 54,44\% (a w całkowitym przywozie-75,82\%). Natomiast udział przywozu gazu z kierunków innych niż wschodni w całkowitym bilansie dostaw w 2011 r. wyniósł 10\% (a w całkowitym przywozie - 14,47\%), podczas gdy w 2014 r. udział ten osiągnął 17,36\% (a w całkowitym przywozie - 24,18\%) [3,4]. Strukturę przywozu gazu w 2014 r. obrazuje rysunek 1.

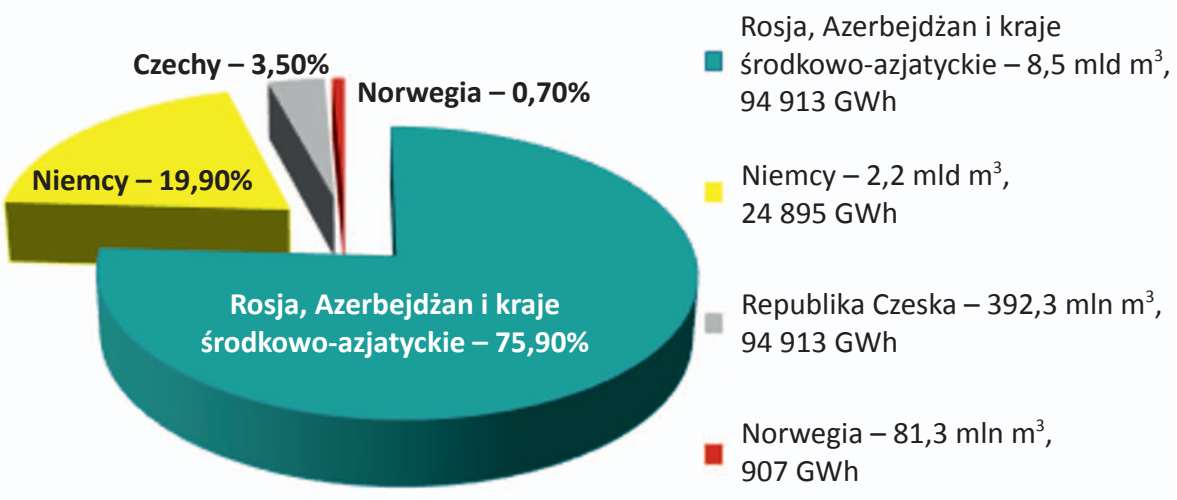

Rys. 1. Struktura przywozu gazu ziemnego z zagranicy w 2014 r. (opracowano na podstawie [4])

Coraz większe możliwości realizowania dostaw gazu za pośrednictwem interkonektorów łączących polski system przesyłowy z systemami przesyłowymi niemieckim i czeskim są następstwem zrealizowanych inwestycji rozbudowy przepustowości połączeń międzysystemowych w Lasowie i w Cieszynie, a także uruchomienia tzw. rewersu fizycznego na polskim odcinku gazociągu jamalskiego, w punkcie Mallnow na granicy polsko-niemieckiej (możliwość przesyłu z kierunku Niemiec 2,3 $\mathrm{mld} \mathrm{m}^{3} /$ rok). W toku są również projekty inwestycyjne dotyczące dalszej rozbudowy inter- konektorów w Cieszynie i Lasowie oraz budowa połączenia międzysystemowego z Litwą, które ma zapewnić zdolności przesyłowe szacowane na $2,4 \mathrm{mld} \mathrm{m}^{3} /$ rok w kierunku Litwy, przy założeniu rozbudowy tych zdolności do pozio$\mathrm{mu} 4,1 \mathrm{mld} \mathrm{m}^{3} /$ rok w drugim etapie, oraz zdolności przesyłowe szacowane na $1 \mathrm{mld} \mathrm{m}^{3} /$ rok w kierunku Polski [4].

Mimo zwiększającego się sukcesywnie poziomu dywersyfikacji dostaw gazu Polska nadal pozostaje nadmiernie uzależniona od dostaw realizowanych z jednego źródła.

W 2014 r. Minister Gospodarki przeprowadził ocenę ryzyka związanego $\mathrm{z}$ bezpieczeństwem dostaw gazu ziemnego do Polski, której wyniki zostały zaprezentowane $\mathrm{w}$ treści planu działań zapobiegawczych opracowanego w 2014 r. W świetle wyników przeprowadzonej oceny aktualnie przyjmuje się, że w przypadku wstrzymania dostaw trzema głównymi gazociągami zaopatrującymi Europę (Nord Stream, Jamał, Braterstwo) nie będzie możliwości realnego zapewnienia stabilnych dostaw gazu ziemnego w Europie Środkowej [17]. Należy w związku z tym wskazać, że głównym celem Polityki Energetycznej Polski do 2030 r. (PEP 2030) w obszarze gazu pozostaje zapewnienie bezpieczeństwa energetycznego kraju poprzez dywersyfikację źródeł i kierunków dostaw gazu ziemnego [16]. W tym kontekście trzeba podkreślić, że terminal LNG w Świnoujściu stanowi jedyne wejście do KSP, w którym możliwa jest realizacja stabilnych dostaw znaczących wolumenów gazu ziemnego z innych niż dotychczasowe źródeł (dywersyfikacja dotyczy zatem w tym przypadku również źródeł, a nie tylko kierunków dostaw).

\section{Znaczenie terminalu LNG dla bezpieczeństwa energetycznego Polski}

Biorąc pod uwagę opisane powyżej okoliczności, należy uznać, że głównym narzędziem mającym zapewnić Polsce bezpieczeństwo energetyczne poprzez realną dywersyfikację źródeł dostaw gazu jest terminal LNG w Świnoujściu, o zdolnościach regazyfikacji na poziomie $5 \mathrm{mld} \mathrm{m}^{3} / \mathrm{rok}$,

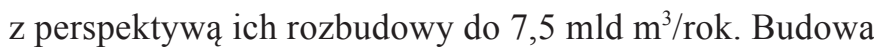
terminalu oraz zapewnienie do niego dostaw skroplonego gazu LNG stanowią działania służące realizacji priorytetu zapewnienia bezpieczeństwa dostaw paliw gazowych, wymienione w PEP 2030, w załączniku 3, w ramach priorytetu II Wzrost bezpieczeństwa dostaw paliw i energii, działanie 2.12 Budowa terminalu do odbioru gazu skroplonego (LNG). W ramach działania 2.12 Minister Skarbu
Państwa został wskazany jako podmiot odpowiedzialny, a spółka Polskie Górnictwo Naftowe i Gazownictwo SA (dalej: PGNiG) - jako podmiot komercyjny rekomendowany do zawarcia kontraktów na dostawy gazu skroplonego do terminalu LNG. Z kolei spółka Polskie LNG S.A. (dalej: PLNG) została wskazana w PEP 2030 jako podmiot komercyjny rekomendowany do przeprowadzenia budowy terminalu, do uzyskania koncesji na regazyfikację LNG oraz do wystąpienia o współfinansowanie inwestycji z funduszy europejskich w ramach Programu Operacyjnego Infrastruktura i Środowisko oraz European Economic Plan for Recovery [16]. Znaczenie inwestycji budowy terminalu LNG w Świnoujściu i inwestycji z nią powiąza- 
nych podkreśla uchwalenie ustawy terminalowej, regulującej szczególne zasady przygotowania, realizacji i finansowania inwestycji w zakresie terminalu LNG [20].

Na gruncie strategicznych dokumentów unijnych terminal LNG w Świnoujściu jest uznawany za kluczową infrastrukturę energetyczną służącą realizacji celu zwiększenia bezpieczeństwa energetycznego. W komunikacie Komisji Europejskiej (KE) z 16 października 2014 r. w sprawie odporności europejskiego systemu gazowego w krótkim okresie. Przygotowanie na możliwe zaktócenia dostaw ze Wschodu jesienia i zima 2014/2015 r. stwierdzono, że możliwość dodatkowego przesyłania gazu gazociągami do Unii Europejskiej (UE) jest ograniczona, a niektóre państwa członkowskie mają ograniczony dostęp do innych gazociągów niż rosyjskie, w związku z czym LNG ma kluczowe znaczenie jako alternatywa pozwalająca na zwiększenie dostaw w przypadku poważnych niedoborów [12]. Zgodnie z europejską strategią bezpieczeństwa energetycznego z 28 maja 2014 r. najbardziej palącą kwestię dotyczącą bezpieczeństwa dostaw energii stanowi silne uzależnienie od jednego zewnętrznego dostawcy, w związku z czym priorytetem jest dostęp do bardziej zróżnicowanych zasobów gazu ziemnego, a jednocześnie utrzymanie importu znacznych ilości od wiarygodnych dostawców. Na gruncie postanowień tej strategii LNG uważa się za główne i coraz ważniejsze potencjalne źródło dywersyfikacji w nadchodzących latach, a budowa terminalu LNG w Świnoujściu została wymieniona jako jeden z projektów o krytycznym znaczeniu dla bezpieczeństwa energetycznego UE w perspektywie krótko- i średnioterminowej [13]. Rozbudowa terminalu LNG w Świnoujściu została z kolei wskazana pod pozycją 8.7 na unijnej liście projektów będących przedmiotem wspólnego zainteresowania w ramach Priorytetowego korytarza: Plan działań w zakresie połaczeń międzysystemowych na rynku energii państw baltyckich dla gazu [18].
W ramach realizacji działań określonych w PEP 2030 PGNiG w dniu 29 czerwca 2009 r. zawarło umowę na dostawy skroplonego gazu ziemnego (LNG) z Qatargas Operating Company Ltd., zgodnie z którą dostawy LNG do terminalu LNG w Świnoujściu będą realizowane przez okres 20 lat w wysokości około $1 \mathrm{mln}$ ton LNG rocznie (około $1,5 \mathrm{mld} \mathrm{m}^{3}$ ) [6]. Ponadto PGNiG zakontraktowało zdolności terminalu LNG w Świnoujściu w ramach procedury Open Season przeprowadzonej przez PLNG w 2009 r., w której mogli brać udział również inni uczestnicy rynku na równych, niedyskryminacyjnych i transparentnych zasadach. Całkowite zdolności terminalu (moc regazyfikacji) udostępnione na zasadzie TPA wyniosły $570000 \mathrm{~m}^{3} / \mathrm{h}$. W ramach procedury PLNG przydzieliło zdolności terminalu wyłącznie na rzecz PGNiG (które jako jedyne złożyło wiążące zamówienie). Przydzielona PGNiG zdolność to $370000 \mathrm{~m}^{3} / \mathrm{h}$, tj. około $65 \%$ udostępnianych zdolności terminalu. W dniu 18 marca 2010 r. zawarta została umowa na zakup usługi regazyfikacji, na podstawie której PLNG zobowiązało się świadczyć na rzecz PGNiG usługi regazyfikacji gazu LNG w terminalu LNG w Świnoujściu przez okres 20 lat. Pozostałe zdolności terminalu (około 35\%) nie zostały zakontraktowane $[5,9]$.

Uwzględniając powyższe, należy przyjąć, że poprzez działania obejmujące: realizację przez PLNG budowy terminalu LNG w Świnoujściu, udostępnianie przez PLNG zdolności terminalu w procedurze Open Season, jak również zawarcie przez PGNiG kontraktów długoterminowych umożliwiających realizację dostaw gazu za pośrednictwem terminalu (na dostawy LNG do terminalu i na świadczenie usług regazyfikacji LNG) realizowane są zadania i cele określone w PEP 2030 oraz w europejskiej strategii bezpieczeństwa energetycznego, w szczególności strategiczny cel w postaci zwiększania bezpieczeństwa energetycznego Polski poprzez dywersyfikację źródeł dostaw gazu.

\section{Koszty dywersyfikacji - uzasadnienie dla wdrożenia mechanizmu wsparcia}

Podejmując opisane powyżej działania w obszarze bezpieczeństwa energetycznego, PGNiG i PLNG ponoszą ryzyka gospodarcze związane z przyszłą sytuacją na rynku gazu, w szczególności ryzyko dotyczące poziomu konkurencyjności cenowej dostaw gazu realizowanych za pośrednictwem terminalu LNG w Świnoujściu względem dostaw dostarczanych za pośrednictwem innych punktów wejścia do KSP. Warto w związku z tym wskazać ryzyka gospodarcze identyfikowane przez PGNiG w Strategii GK PGNiG na lata 2014-2022 związane z realizacją dostaw gazu przez terminal na podstawie kontraktów długoterminowych. Chodzi m.in. o istotne spadki cen gazu obserwowane na rynkach europejskich w ostatnim czasie oraz tendencję do odchodzenia od wiązania rynkowej ceny gazu z notowaniami produktów ropopochodnych (taka formuła została przyjęta w kontraktach jamalskim i katarskim). Wynikające z powyższych okoliczności zróżnicowanie formuł cenowych w kontraktach PGNiG i jego konkurentów generuje ryzyko presji cenowej na PGNiG [7]. Uwzględniając dodatkowo koszty regazyfikacji LNG i wprowadzenia gazu do systemu przesyłowego, należy wskazać, że koszty realizacji dostaw paliw gazowych za pośrednictwem terminalu potencjalnie mogą się okazać wyższe od kosztów dostaw realizowanych przez inne punkty wejścia do KSP. Konsekwencją może być rela- 
tywnie niewielki popyt na usługi terminalu, co przy aktualnym modelu taryfowym może się wiązać z niewspółmiernie wysokimi stawkami regazyfikacji (w porównaniu do innych konkurencyjnych wobec Świnoujścia terminali europejskich). W związku z powyższym istnieje ryzyko, że trudno będzie zapewnić konkurencyjność terminalu względem innych punktów wejścia do KSP, a tym samym potencjał budowania bezpieczeństwa energetycznego za pomocą terminalu może nie zostać w pełni wykorzystany.

Należy przy tym pamiętać, że podpisując długoterminową umowę na dostawy LNG z Qatargas Operating Company Ltd., PGNiG realizowało politykę państwa, kierując się względami bezpieczeństwa energetycznego Polski, a nie wyłącznie przesłankami ekonomicznymi [2]. W ocenie Najwyższej Izby Kontroli, która kontrolowała okoliczności zawarcia kontraktu katarskiego w 2010 r., przystąpienie do rozmów dotyczących długoterminowych dostaw LNG do Polski z partnerem katarskim było działaniem gospodarnym, a podpisane za zgodą Ministra Skarbu Państwa umowy należycie zabezpieczają interesy strony polskiej [23]. Dodatkowo należy zauważyć, że warunkiem utrzymania zdolności technicznej terminalu LNG w Świnoujściu do świadczenia usług regazyfikacji jest ciągłe wykorzystanie mocy regazyfikacji terminalu co najmniej na poziomie $75000 \mathrm{~m}^{3} / \mathrm{h}$ (minimalna moc regazyfikacji, stanowiąca $13,15 \%$ mocy regazyfikacji terminalu) [8]. Można zatem przyjąć, że gdyby PGNiG nie zakontraktowało zdolności terminalu (w ramach realizacji zadań wyznaczonych w PEP 2030), to prawdopodobnie minimum technologiczne warunkujące działanie terminalu nie zostałoby zapewnione przez rynek z uwagi na niewielki popyt na zdolności terminalu.
Podsumowując dotychczasowe uwagi, należy dojść do wniosku, że w obecnej sytuacji koszty i ryzyko gospodarcze zapewnienia dywersyfikacji dostaw gazu do Polski za pomocą terminalu LNG w Świnoujściu ponosi dwóch uczestników rynku, tj. PGNiG i PLNG, wykonujących zadania określone przez państwo w PEP 2030. Opisane powyżej ryzyka gospodarcze należy uznać za istotne, gdyż potencjalnie mogą one zagrozić stabilności finansowej funkcjonowania terminalu LNG, a tym samym realizacji głównego celu w postaci bezpieczeństwa energetycznego zapewnianego przez terminal.

Powyższe okoliczności stanowią podstawowy kontekst i zarazem uzasadnienie prac nad wdrożeniem w Polsce mechanizmów wsparcia bazujących na koncepcji tzw. socjalizacji kosztów funkcjonowania terminalu LNG w Świnoujściu. Koncepcja ta nawiązuje do rozwiązań wdrożonych już w innych krajach UE i polega na zrównoważeniu obciążeń związanych z funkcjonowaniem terminalu poprzez wprowadzenie w drodze ustawy opłaty, uwzględnianej w taryfach dystrybucyjnych i przesyłowej, ponoszonej przez wszystkich odbiorców gazu i mającej pokryć część kosztów funkcjonowania terminalu. System wsparcia ma w założeniu umożliwić ustalenie opłat za usługi regazyfikacji na poziomie zbliżonym do opłat obserwowanych w UE, co zwiększy konkurencyjność terminalu i dostępność cenową usług regazyfikacji dla zainteresowanych uczestników rynku. Z kolei wzrost konkurencyjności dostaw gazu przez terminal względem innych źródeł dostaw przełoży się na poprawę bezpieczeństwa energetycznego Polski. Koncepcję socjalizacji kosztów funkcjonowania terminalu kierunkowo poparł Prezes URE, natomiast jej wdrożenie będzie wymagało przyjęcia odpowiednich rozwiązań ustawowych [2].

\section{Ramy prawne mechanizmu wsparcia terminalu LNG w Świnoujściu}

Mechanizmy wspierania działalności operacyjnej przedsiębiorstw energetycznych powinny podlegać ocenie na gruncie przepisów prawa dotyczących pomocy publicznej. W tym aspekcie, biorąc pod uwagę pozytywne decyzje Komisji Europejskiej, w szczególności w sprawie pomocy publicznej dla terminalu LNG w Kłajpedzie, należy przyjąć, że w dotychczasowej praktyce Komisja Europejska uznawała za dopuszczalne przedstawiane do oceny mechanizmy wsparcia infrastruktury LNG, kwalifikując je w następujący sposób:

- w części przeznaczonej na pokrycie kosztów budowy terminalu LNG - jako indywidualną pomoc publiczną na infrastrukturę energetyczną, dopuszczalną na podstawie art. 107 ust. 3 pkt c Traktatu o Funkcjonowaniu Unii Europejskiej (TFUE);

- w części przeznaczonej na pokrycie kosztów operacyjnych terminalu LNG - jako rekompensatę z tytułu usług świadczonych w ogólnym interesie gospodarczym (dalej: UOIG), dopuszczalną na podstawie art. 106 ust. 2 TFUE $[10,19]$.

Kryterium decydującym o zastosowaniu jednej ze wskazanych powyżej podstaw prawnych jest rodzaj kosztów, których pokryciu ma służyć mechanizm wsparcia. $Z$ orzecznictwa Trybunału Sprawiedliwości UE (TSUE) oraz decyzji KE ws. terminalu LNG w Kłajpedzie wynika, że pomoc służąca pokryciu kosztów operacyjnych, które należałoby ponieść przy normalnym zarządzaniu przedsiębiorstwem lub prowadzeniu zwyczajnej działalności (np. związanych z eksploatacją i utrzymaniem infrastruktury), nie jest uznawana za zgodną ze wspólnym rynkiem na podstawie art. 107 ust. 3 lit. c TFUE, natomiast może być dopuszczona jako rekompensata $\mathrm{z}$ tytułu UOIG, jeżeli jest niezbędna do świadczenia UOIG i nie generuje zakłóceń konkurencji sprzecznych 
z interesem UE [21]. Zakładając, że potencjalny system wsparcia dla terminalu LNG w Świnoujściu ma służyć pokryciu części kosztów jego funkcjonowania, należy przyjąć, że tego rodzaju pomoc można kwalifikować jako rekompensatę z tytułu UOIG, pod warunkami opisanymi poniżej.

Na przełomie lat 2011 i 2012 KE przyjęła pakiet regulacji dotyczących UOIG, w tym zasady ramowe oraz komunikat w sprawie stosowania reguł UE w dziedzinie pomocy państwa w formie rekompensaty z tytułu UOIG. Na gruncie ww. regulacji UOIG to usługi powierzone przedsiębiorstwu przez państwo, które nie są dostępne na rynku, i świadczenia, których dane przedsiębiorstwo, kierując się wyłącznie własnym interesem gospodarczym, nie podjęłoby się lub nie podjęłoby się w tym samym zakresie lub na tych samych warunkach. Koszty świadczenia UOIG mogą być rekompensowane z zasobów państwa, przy czym transfer tych zasobów może polegać m.in. na finansowaniu UOIG z opłat lub składek wnoszonych przez niektóre przedsiębiorstwa lub użytkowników, nakładanych przez państwo oraz zarządzanych i przydzielanych pod kontrolą państwa. Rekompensata z tytułu UOIG nie stanowi pomocy publicznej, jeśli spełnione są cztery warunki określone w wyroku TSUE w sprawie Altmark (przedstawione poniżej na rysunku 2) [14, 15, 22].

Ponadto zasady ramowe precyzują warunki uznania rekompensaty z tytułu UOIG za zgodną z art. 106 ust. 2 TFUE, m.in. pomoc musi być przyznana na faktyczną i prawidłowo zdefiniowaną UOIG, a wykonywanie UOIG musi być powierzone przedsiębiorstwu lub przedsiębiorstwom na mocy jednego lub większej liczby aktów, w których należy określić m.in. opis mechanizmu rekompensaty. Kwota rekompensaty nie może przekraczać kwoty niezbędnej do pokrycia całości lub części kosztów wywiązywania się ze zobowiązań z tytułu UOIG wraz z rozsądnym zyskiem. Jeżeli rekompensata z tytułu UOIG nie spełnia wszystkich warunków określonych w wyroku Altmark, wówczas taka rekompensata jest kwalifikowana jak pomoc publiczna, która co do zasady powinna być notyfikowana Komisji Europejskiej w trybie art. 108 ust. 3 TFUE. Pomoc taka może nadal zostać uznana

\section{Wyrok Altmark}

KE przyjmując pakiet dokumentów dotyczących UOIG oparła się wyroku ETS w sprawie C - 280/00 Altmark, w świetle którego rekompensata z tytułu UOIG nie stanowi pomocy państwa, jeśli spełnione są równocześnie cztery warunki:

przedsiębiorstwo będące beneficjentem musi wywiązywać się ze zobowiązań z tytułu świadczenia UOIG, a zobowiązania te muszą być jasno zdefiniowane

parametry, na podstawie których obliczana jest rekompensata, muszą zostać określone z wyprzedzeniem w obiektywny i przejrzysty sposób

rekompensata nie może przekraczać kwoty niezbędnej do pokrycia całości lub części kosztów poniesionych w trakcie wywiązywania się ze zobowiązań z tytułu UOIG, przy uwzględnieniu odpowiednich wpływów i rozsądnego zysku,

w przypadku gdy powierzenie świadčenia UOIG nie dokonuje się zgodnie z

konkurencyjną procedurą udzielania zamówień publicznych, poziom rekompensaty należy określić na podstawie analizy kosztów świadczenia UOIG, jakie poniosłoby

typowe, dobrze zarządzane przedsiębiorstwo dysponujące odpowiednimi środkami.

Rys. 2. Najważniejsze tezy wyroku w sprawie Altmark (opracowano na podstawie [22])

za zgodną z rynkiem wewnętrznym na podstawie art. 106 ust. 2 TFUE, zgodnie $\mathrm{z}$ zasadami przedstawionymi na rysunku 3. KE zaleca przy tym podjęcie kontaktów przedzgłoszeniowych (tzw. prenotyfikacja) w sprawach, w których pojawiają się wyjątkowe aspekty lub problemy. W ramach prenotyfikacji państwo członkowskie uzyskuje nieformalne wstępne wskazówki dotyczące planowanej pomocy [15].

Zgodnie z pkt 10 komunikatu KE ws. stosowania art. 106 ust. 2 TFUE zasady w nim określone obowiązują bez

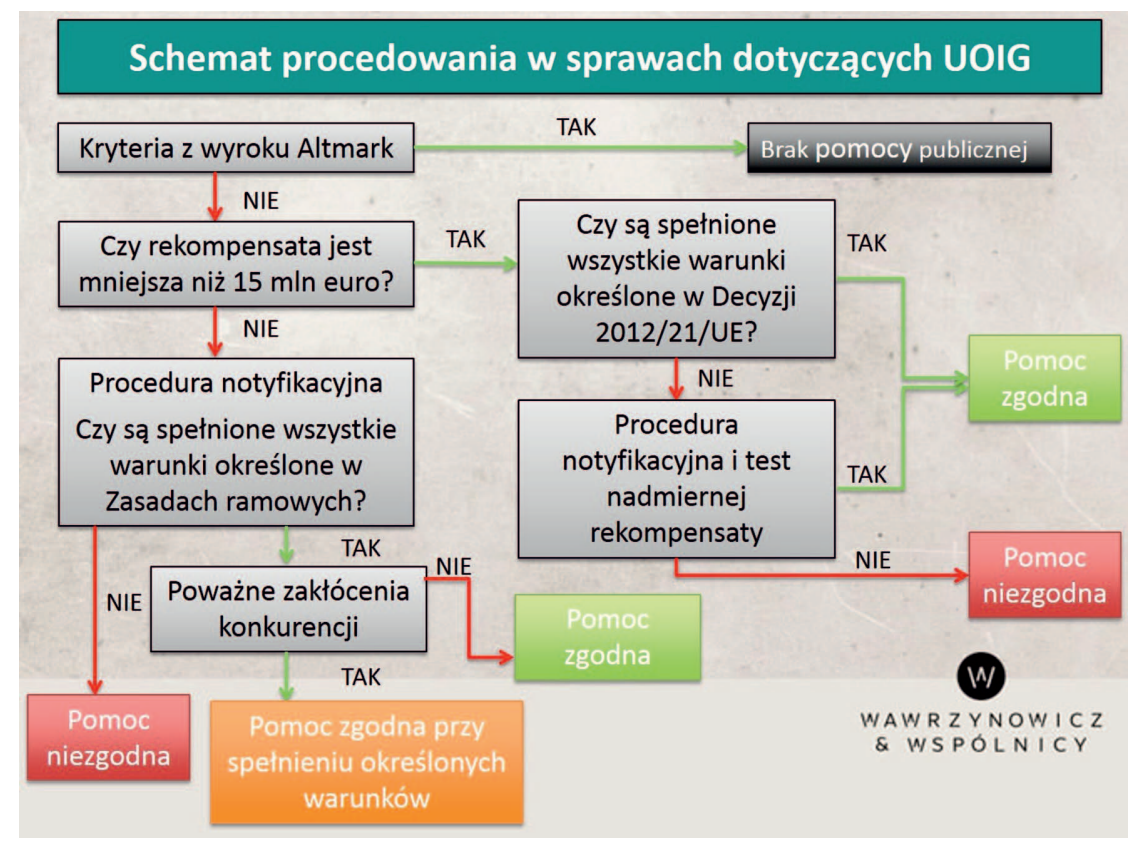

Rys. 3. Schemat procedowania w sprawach dotyczących UOIG (opracowanie własne na podstawie [1]) 
uszczerbku dla dodatkowych wymogów wynikających z Traktatu lub sektorowych przepisów unijnych. W konsekwencji powierzenie UOIG w celu zapewnienia bezpieczeństwa dostaw gazu wymaga uwzględnienia m.in. regulacji zawartych w dyrektywie 2009/73/WE (dyrektywa gazowa), w szczególności dotyczących nakładania obowiązków użyteczności publicznej (public service obligation - PSO). Niezależnie za- tem od konieczności weryfikacji mechanizmu wsparcia terminalu w Świnoujściu na gruncie regulacji dotyczących pomocy publicznej - niezbędne będzie zapewnienie zgodności powierzenia UOIG z przepisami dotyczącymi nakładania PSO, w szczególności z art. 3 ust. 2 dyrektywy gazowej, oraz dokonanie notyfikacji KE o przyjętych PSO, zgodnie $\mathrm{z}$ art. 3 ust. 11 dyrektywy gazowej [11].

\section{Przykład mechanizmu wsparcia dla terminalu LNG w Kłajpedzie}

Rozważając możliwe podstawy prawne wdrożenia mechanizmu wsparcia funkcjonowania terminalu LNG w Świnoujściu, warto przyjrzeć się systemowi wsparcia terminalu LNG w Kłajpedzie, notyfikowanemu KE w 2013 r. i uregulowanemu w ustawie, obejmującemu następujące elementy:

- system obejmuje opłaty nakładane na użytkowników systemu przesyłowego w taryfie operatora systemu przesyłowego, wypłacane na rzecz operatora terminalu AB Klaipedos Nafta (dalej: KN), na polecenie regulatora, na pokrycie m.in. kosztów: utrzymania terminalu, obejmującego pływający magazyn LNG oraz jednostkę regazyfikacyjną; wynagrodzenia; ubezpieczenia; wynajmu nabrzeża itp.;

- wprowadzono obowiązek kupowania minimalnych ilości gazu importowanego przez terminal LNG przez wszystkie przedsiębiorstwa działające w segmencie wytwarzania energii elektrycznej i ciepła. Minimalną ilość gazu ziemnego objętą powyższym obowiązkiem, niezbędną dla zapewnienia stabilnego działania terminalu, określa rząd. Obowiązek zakupu minimalnych ilości gazu planowany jest na okres 10 lat, a gaz ten ma być kupowany od wyznaczonego dostawcy, który z kolei został ustawowo zobowiązany do zapewnienia dostaw LNG do terminalu LNG.
Oceniając litewski system wsparcia, KE uznała, że w przypadku Litwy, z uwagi na jej uzależnienie od jednego dostawcy, uruchomienie i funkcjonowanie terminalu LNG stanowi UOIG uzasadnione bezpieczeństwem energetycznym Litwy. KE doszła też do przekonania, że KN nie eksploatowałby terminalu bez nałożenia na niego stosownego obowiązku i przyznania mu rekompensaty z tytułu UOIG (tj. gdyby kierował się wyłącznie własnym interesem gospodarczym). Ponadto w przypadku, w którym część kosztów funkcjonowania terminalu nie byłaby pokrywana $\mathrm{z}$ rekompensaty, a zamiast tego koszty zostałyby przeniesione w opłatach regazyfikacyjnych, nastąpiłoby znaczne podwyższenie tych opłat, a to z kolei spowodowałoby brak popytu na usługi terminalu. KE uznała także, że wsparcie skutkujące niższą taryfą regazyfikacyjną nie będzie zakłócać konkurencji ani wpływać na wymianę handlową $\mathrm{w}$ sposób sprzeczny $\mathrm{z}$ interesem UE. Przeciwnie - wsparcie terminalu LNG i jego uruchomienie połączy Litwę z europejskim rynkiem gazu i światowym rynkiem LNG, a to będzie stymulowało konkurencję na rynku hurtowym i detalicznym. W związku z powyższym KE uznała, że system wsparcia funkcjonowania terminalu LNG w Kłajpedzie jest zgodny z rynkiem wewnętrznym UE [10].

\section{Podsumowanie}

Uwzględniając opisane w artykule okoliczności dotyczące znaczenia terminalu LNG w Świnoujściu dla bezpieczeństwa energetycznego Polski, ryzyka gospodarcze po stronie PGNiG i PLNG związane z realizacją zadań określonych w PEP 2030, mających na celu uruchomienie i stabilne funkcjonowanie terminalu, oraz regulacje prawne w zakresie pomocy publicznej, należy przyjąć, że istnieją przesłanki oraz ramy regulacyjno-prawne umożliwiające wdrożenie mechanizmów wsparcia dla terminalu LNG w Świnoujściu, obejmujących tzw. socjalizację kosztów jego funkcjonowania, które w ocenie autorów znajdą zapewne akceptację po stronie Komisji Europejskiej.

Wydaje się także, że projektowane mechanizmy wsparcia powinny nawiązywać do rozwiązań, które zostały już wdrożone i zaakceptowane przez Komisję Europejską, w szczegól- ności korzystać z doświadczeń Litwy w tym zakresie. Należy ponadto wskazać, że przyjęte dotąd dokumenty rządowe, w szczególności PEP 2030, mogą uzasadniać tezę, że doszło do powierzenia PGNiG i PLNG przez państwo świadczenia usług w ogólnym interesie gospodarczym, jednakże wymagają one uzupełnienia o stosowne regulacje ustawowe. Zwiększenie konkurencyjności terminalu LNG w Świnoujściu dla uczestników rynku oraz zagwarantowanie funkcjonowania terminalu w sposób stabilny i ciągły leży w ogólnym interesie gospodarczym Polski, rozumianym jako zapewnienie bezpieczeństwa energetycznego poprzez zwiększenie dywersyfikacji źródeł dostaw paliw gazowych i zmniejszenie uzależnienia Polski od importu gazu ze Wschodu.

Wprowadzenie w drodze ustawy opłaty systemowej, w wysokości ustalonej decyzją regulatora, oraz przezna- 
czenie zgromadzonych w ten sposób środków na wsparcie operacyjne funkcjonowania terminalu LNG w Świnoujściu, podobnie jak ma to miejsce w opisanym powyżej przykła- dzie litewskim, stworzy szansę na pełne wykorzystanie potencjału terminalu jako instrumentu budowania bezpieczeństwa energetycznego Polski.

Prosimy cytować jako: Nafta-Gaz 2016, nr 6, s. 436-442, DOI: 10.18668/NG.2016.06.07

Artykuł nadesłano do Redakcji 5.01.2016 r. Zatwierdzono do druku 16.03.2016 r.

Artykuł powstał na podstawie referatu zaprezentowanego na Konferencji Naukowo-Technicznej FORGAZ 2016 Techniki $i$ technologie dla gazownictwa - pomiary, badania, eksploatacja, zorganizowanej przez INiG - PIB w dniach 13-15 stycznia 2016 r. w Muszynie.

\section{Literatura}

[1] European Commission SGEI Analysis Tree. http://ec.europa.eu/ competition/state_aid/overview/analysis_tree_en.pdf (dostęp: 5.01.2016).

[2] Furman T.: Odbiorcy gazu zapłaca więcej. Rzeczpospolita 2015, 5 października, http://www.rp.pl/Energianews/ 310059774-Odbiorcy-gazu-zaplaca-wiecej.html (dostęp: 5.01.2016).

[3] Minister Gospodarki: Sprawozdanie z wyników monitorowania bezpieczeństwa dostaw paliw gazowych za okres od dnia 1 stycznia 2012 r. do dnia 31 grudnia 2012 r. Warszawa 2013.

[4] Minister Gospodarki: Sprawozdanie z wyników monitorowania bezpieczeństwa dostaw paliw gazowych za okres od dnia 1 stycznia 2014 r. do dnia 31 grudnia 2014 r. Warszawa 2015.

[5] Polskie Górnictwo Naftowe i Gazownictwo SA: Raport bieżacy $n r$ 12/2010. 18 marca 2010 r., http://www.pgnig.pl/relacje-inwestorskie/raporty-gieldowe/biezace (dostęp: 5.01.2016).

[6] Polskie Górnictwo Naftowe i Gazownictwo SA: Raport bieżacy $n r$ 78/2009. 29 czerwca 2009 r., http://www.pgnig.pl/relacje-inwestorskie/raporty-gieldowe/biezace (dostęp: 5.01.2016).

[7] Polskie Górnictwo Naftowe i Gazownictwo SA: Strategia GK PGNiG na lata 2014-2022. Grudzień 2014, http://www.pgnig. pl (dostęp: 5.01.2016).

[8] Polskie LNG: Instrukcja Terminalu. http://www.polskielng.pl/ uslugi/instrukcja-terminalu/ (dostęp: 5.01.2016).

[9] Polskie LNG: Open Season. http://www.polskielng.pl/archiwum/ open-season/ (dostęp: 5.01.2016).

\section{Akty prawne i normatywne}

[10] Decyzja Komisji Europejskiej z dnia 20 listopada 2013 r. w sprawie C(2013) 7884 final (State aid SA.36740 (2013/NN) - Lithuania. Aid to Klaipedos Nafta - LNG Terminal).

[11] Dyrektywa Parlamentu Europejskiego i Rady 2009/73/WE z dnia 13 lipca 2009 r. dotycząca wspólnych zasad rynku wewnętrznego gazu ziemnego i uchylająca dyrektywę 2003/55/WE (Dz. Urz. UE L 211 z 14.08.2009, s. 94).

[12] Komunikat Komisji do Parlamentu Europejskiego i Rady z dnia 16 października 2014 r. w sprawie odporności europejskiego systemu gazowego w krótkim okresie. Przygotowanie na możliwe zakłócenia dostaw ze Wschodu jesienią i zimą 2014/2015 r. COM(2014) 654

[13] Komunikat Komisji do Parlamentu Europejskiego i Rady z dnia
28 maja 2014 r. - Europejska strategia bezpieczeństwa energetycznego. COM(2014) 330.

[14] Komunikat Komisji z dnia 11 stycznia 2012 r. w sprawie stosowania reguł Unii Europejskiej w dziedzinie pomocy państwa w odniesieniu do rekompensaty $\mathrm{z}$ tytułu usług świadczonych w ogólnym interesie gospodarczym (2012/C 8/02) (komunikat KE ws. stosowania art. 106 ust. 2 TFUE).

[15] Komunikat Komisji z dnia 11 stycznia 2012 r. - Zasady ramowe Unii Europejskiej dotyczące pomocy państwa w formie rekompensaty z tytułu świadczenia usług publicznych (2011) (2012/C 8/03) (zasady ramowe).

[16] Obwieszczenie Ministra Gospodarki z dnia 21 grudnia 2009 r w sprawie polityki energetycznej państwa do 2030 r. (M.P. z 2010 r. Nr 2, poz. 11).

[17] Plan Działań Zapobiegawczych opracowany na podstawie art. 4 Rozporządzenia Parlamentu Europejskiego i Rady (UE) Nr 994/2010 z dnia 20 października 2010 r. w sprawie środków zapewniających bezpieczeństwo dostaw gazu ziemnego i uchylenia dyrektywy Rady 2004 /67/WE. Minister Gospodarki, 2014, edycja II.

[18] Rozporządzenie Parlamentu Europejskiego i Rady (UE) nr 347/2013 w sprawie wytycznych dotyczących transeuropejskiej infrastruktury energetycznej, uchylające decyzję nr 1364/2006/WE oraz zmieniające rozporządzenia (WE) nr 713/2009, (WE) nr 714/2009 i (WE) nr 715/2009 (Dz. Urz. UE L 115 z 25.04.2013, s. 39).

[19] Traktat o funkcjonowaniu Unii Europejskiej z dnia 30 kwietnia 2004 r. (Dz. U. z 2004 r. Nr 90, poz. 864/2).

[20] Ustawa z dnia 24 kwietnia 2009 r. o inwestycjach w zakresie terminalu regazyfikacyjnego skroplonego gazu ziemnego w Świnoujściu (Dz. U. z 2009 r. Nr 84, poz. 700 z późn. zm.).

[21] Wyrok Sądu pierwszej instancji (druga izba) z dnia 31 maja 2006 r. w sprawie T-354/99, Siemens SA przeciwko Komisji Wspólnot Europejskich.

[22] Wyrok Trybunału z dnia 24 lipca 2003 r. w sprawie C-280/00, Altmark Trans GmbH i Regierungspräsidium Magdeburg przeciwko Nahverkehrsgesellschaft Altmark $\mathrm{GmbH}$, przy udziale Oberbundesanwalt beim Bundesverwaltungsgericht.

[23] Wystąpienie pokontrolne Najwyższej Izby Kontroli z dnia 4 listopada 2010 r. nr P/10/046, KGP-4101-04-04/2010, w związku z przeprowadzoną w spółce Polskie Górnictwo Naftowe i Gazownictwo S.A. kontrolą działań związanych z zawarciem umów dotyczących dostaw gazu skroplonego z Kataru.

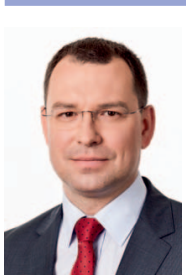

Adam WAWRZYNOWICZ

Radca prawny

Kancelaria Wawrzynowicz i Wspólnicy sp. k.

ul. Paderewskiego 7

61-770 Poznań

E-mail: adam.wawrzynowicz@wawrzynowicz.eu

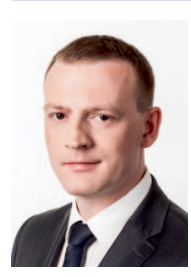

Tomasz BRZEZIŃSKI

Radca prawny

Kancelaria Wawrzynowicz i Wspólnicy sp. k.

ul. Paderewskiego 7

61-770 Poznań

E-mail: tomasz.brzezinski@wawrzynowicz.eu 